\title{
Uterine Corpus Leiomyosarcoma and Endometrial Stromal Sarcoma Clinical TNM Finding v8
}

National Cancer Institute

\section{Source}

National Cancer Institute. Uterine Corpus Leiomyosarcoma and Endometrial Stromal

Sarcoma Clinical TNM Finding v8. NCI Thesaurus. Code C139817.

A clinical finding about one or more characteristics of uterine corpus leiomyosarcoma or endometrial stromal sarcoma, following the rules of the TNM AJCC V8 classification system. 